УдК 329.15(497.1)"1929/1933"

323(497.1)"1929/1933"

Оригиналан научни рад

Примљен: 11.6.2015.

Прихваћен: 14. 7. 2015.

\author{
Dušan BOJKOVIĆ \\ dsnbojkovic@gmail.com
}

\title{
The Communist Party of Yugoslavia during the Autocratic Rule of King Aleksandar Karađorđević
}

\begin{abstract}
This paper presents the results of research made on the stance of the leadership of the Communist Party of Yugoslavia towards the Yugoslav regime during the dictatorship of King Aleksandar Karađorđević, followed by the problem of cooperation between communists and Ustaše and the changes in Party's territorial organization at the beginning of the 1930s. Both archival and published sources of Party's central, provincial and regional subdivisions, as well as newspaper articles and relevant literature have been covered in the research.
\end{abstract}

Keywords: Kingdom of Yugoslavia, Communist Party of Yugoslavia, "dictatorship", Great-Serbian hegemonism, banovinas

The promulgation of "dictatorship"

and the division of state into banovinas

During the second half of the 1920s, the political stage of the Kingdom of Serbs, Croats and Slovenes (hereinafter referred to as: SCS) was marked by numerous tribulations. Fierce conflicts among the ruling parties in the National Assembly undoubtedly pointed to a rift in a society divided over numerous "burning" issues, among which the Croatian issue presented itself as the most significant. Polemical discussions among the People's Radical Party's and Peasant-Democratic Coalition's (hereinafter referred to as: PDC) MPs reached a critical point in 1928. In a heated and tense atmosphere, inside the National Assembly, after a 
set of mutual accusations, insults and threats, on 20 June, Puniša Račić, killed Pavle Radić and Đura Basariček and wounded Ivan Pernar, Ivan Granđa and Stjepan Radić, who succumbed to the wounds on 8 August. ${ }^{1}$ That event had, according to Branko Petranović, "definitely sealed the fate of parliamentarism in the Kingdom of SCS", and opened the door to absolutism. ${ }^{2}$ At the same time, we should keep in mind King Aleksandar's permanent aspiration to absolute rule. ${ }^{3}$

The dilemma whether to "amputate" Croatian territories and form a new state which would encompass all "Serbian lands" or establish absolute rule, was resolved by King Aleksandar's decision to implement the latter solution. Finally, the "Law on Royal Power and High State Administration" from 6 January 1929 annulled the Vidovdan Constitution of 1921 and proclaimed the King as "the holder of all authority in the country" while the "Law on the Protection of Public Safety and State Order" abolished public political life and banned the activity of politi-

1 More on this subject: Б. Глигоријевић, Краљ Александар Карађорђевић, I-III, (Београд, 2002), [В. Gligorijević, King Aleksandar Karađorđević, I-III, (Belgrade, 2002)], II/301-311; I. Dobrivojević, Državna represija u doba diktature kralja Aleksandra 1929-1935, (Beograd, 2006) [State Repression and the Period of King Aleksandar's Dictatorship 1929-1935, (Belgrade, 2006)], 37-43. By the verdict of the Court of Appeal in Belgrade, dated October the $15^{\text {th }} 1929$, Puniša Račić was sentenced to twenty years of prison. The verdict itself says, among other things, how Račić "fired from a revolving gun mark 'Steyr' at the former MP, now deceased Stjepan Radić and with a single shot inflicted upon him a physical injury, which correlates to the final cause of death of the deceased Stjepan Radić", [Archives of Yugoslavia (hereinafter referred to as: AY), Administration of Penitentiaries funds (Požarevac, Sremska Mitrovica, Maribor): items of the convicted communists, box no. 1, document no. IV]. However, there is an opinion in modern historiography that the wounding of Stjepan Radić was not life-threatening from the medical point of view, and that the tragic outcome has occurred in conjunction with Radić's chronic alcoholism and a severe case of diabetes. - B. Petranović, Istorija Jugoslavije, I-III, (Beograd, 1988) [History of Yugoslavia I-III, (Belgrade, 1988)], I/174-175; Ђ. Станковић, Изазов нове историје, I-II, (Београд, 1992-1994) [Đ. Stanković, Challenges of New History, I-II, (Belgrade, 1992-1994)], I/132-133.

2 Petranović, Istorija Jugoslavije, I/175.

3 As an indicator of King Aleksandar Karađorđević's absolutistic nature it has often been mentioned that in the period from 1918 till 1929, out of the 24 government cabinets in total, only two were "disbanded" by the National Assembly, while the others were "toppled" by the monarch himself. - Љ. Димић, Историја српске државности, том III: Србија у Југославији, (Нови Сад, 2001) [Lj. Dimić, History of Serbian Statehood, vol. III: Serbia in Yugoslavia (Novi Sad, 2001)], 98-107; Записници са седница Министарског савета Краљевине Југославије 1929-1931, приредили Љубодраг Димић, Никола Жутић, Благоје Исаиловић (hereinafter referred to as: Записници MC К), (Београд, 2002), Уводна студија, XXXII, [Minutes from the Session of the Ministerial Council of the Kingdome of Yugoslavia 1929-1931, edited by Ljubodrag Dimić, Nikola Žutić, Blagoje Isailović (hereinafter referred to as: Minutes MC KY), (Belgrade, 2002), Introductory Study, XXXII]. 
cal parties and religious associations. ${ }^{4}$ In the 6 January proclamation, the King stepped forth as the guardian of national and state unity, which was greeted "with relief and approval", "by most of the people". ${ }^{5}$ whole set of laws adopted during 1929 and 1930 paved the road to the implementation of national unification, enshrouded in a veil of Yugoslav national identity. ${ }^{6}$

The ideology of integral Yugoslav national identity was further strengthened by the "Law on the Name and the Division of Kingdom into Administrative regions" passed on 3 October 1929. The new name of the country - Kingdom of Yugoslavia - symbolically presented the rejection of the previous concept of preservation of tribal (ethnic) pluralism within a unique "Yugoslav nation".7 The same law proclaimed the division of country into nine territorially-administrative regions. ${ }^{8}$ Even

$4 \quad$ B. Petranović, M. Zečević, Jugoslovenski federalizam. Ideje i stvarnost, tematska zbirka dokumenata, I-II, (Beograd, 1987) [Yugoslav Federalism. Ideas and Reality, thematic collection of documents, I-II, (Belgrade, 1987)], I/293-303.

5 Stanković, op. cit., I/128; Dobrivojević, op. cit., 51-52; Ч. Попов, Велика Србија. Стварност и мит, треће издање, (Сремски Карловци - Нови Сад, 2007) [С̆. Popov, Great Serbia. Reality and Myth, third edition, (Sremski Karlovci - Novi Sad, 2007)], 225-226.

6 More on this topic: I. Dobrivojević, „Sudstvo i sudije u doba Šestojanuarskog režima kralja Aleksandra (1929-1935)“, Tokovi istorije ["Judiciary and Judges in the Sixth of January Dictatorship of King Alexander 1929-1935”, Currents of History], 3-4/2005, 29; Б. Петрановић, Југословенско искуство српске националне интеграције, (Београд, 1993) [В. Petranović, Yugoslav Experience of Serbian National Integration, (Belgrade, 1993), 37-39]; Petranović, Istorija Jugoslavije, [History of Yugoslavia], I/176-185; T. Stojkov, Opozicija u vreme šestojanuarske diktature 1929-1935, (Beograd, 1969) [Opposition in the Time of the Sixth January Dictatorship 1929-1935, (Belgrade, 1969)], 53-72; Dimić, op. cit., 137-143; Љ. Димић, Срби и Југославија. Простор, друштво, политика (поглед с краја века), (Београд, 1998) [Lj. Dimić, Serbs in Yugoslavia. Territory, Socoety, Politics (a view from the end of the century, (Belgrade, 1998)], 124-135; Записници MC КJ, Уводна студија [Minutes MC KY, Introductory Study], XL-XLI.

7 Записници MC KJ [Minutes MC KY], 100.

8 In article no. 2 of the "Law on the Name and the Division of Kingdom into Administrative Regions" from 3 October 1929 the following banovinas are listed: Banovina of Drava with an administrative seat at Ljubljana, Banovina of Sava with an administrative seat at Zagreb, Maritime Banovina with an administrative seat at Split, Banovina of Vrbas with an administrative seat at Banja Luka, Banovina of Drina with an administrative seat at Sarajevo, Banovina of Danube with an administrative seat at Novi Sad, Banovina of Vardar with an administrative seat at Skopje, Banovina of Morava with an administrative seat at Niš, Banovina of Zeta with an administrative seat at Cetinje. Area of the City of Belgrade with Zemun and Pančevo was separated as a special administrative unit under the jurisdiction of the Ministry of Interior Affairs. - Алманах Краљевине Југославије. IV јубиларни свезак: 1929-1931 (hereinafter referred to as: Алманах KJ), друго издање, (Загреб, 1932) [Almanac of the Kingdome of Yugoslavia, IV jubilee volume: 1929-1931 (hereinafter referred to as: Almanac KY), second edition, (Zagreb, 1932)], 143. 
though the new administrative borders were justified by "the most objective" criteria, ${ }^{9}$ the forming of banovinas was undertaken primarily with the aim of achieving a tighter centralization of government rule and the prevention of further development of disintegrative processes and separatism. The omnipresent rule of the King hindered banovinas from achieving higher degree of autonomy. In accordance with the new national identification, government officials said that this division established a precondition "for our people - within the harmony of national unity - to completely enjoy a free and peaceful life, to completely devote themselves to cultural and economic advancement, and as such, to be of greater use to the international community, thus remaining a completely reliable element of international peace". ${ }^{10}$

Disregarding the natural and historical boundaries, banovinas broke up old provinces, which - in an administrative sense - lost their outlines and names which had lasted for several centuries. During the drawing of new "internal borders" a lot of attention was paid to the strengthening of Serbian national element in the banovinas by securing the majority of Orthodox Christians. ${ }^{11}$ On the other hand, contrary to Slovenia, which was contained within the boundaries of the Banovina of Drava, and contrary to the "Croatian lands" (Slavonia, Croatia, Dalmatia) which in most part were contained within the Banovina of Sava and Maritime Banovina, and contrary to Montenegro, Macedonia and Vojvodina, whose historical continuity was not drastically jeopardized by the creation of larger administrative units (Banovinas of Zeta, Vardar and Danube), the territory of Serbia and Bosnia and Herzegovina was broken up respectively into five and four

9 At the XXIII session of the Ministerial Council held on 3 October 1929 it was said that with the new division of the country into banovinas "the central government is now unburdened and administration [...] is simplified and more effectively organized" and that by transferring "many important jurisdictions from the central body, [...] a more expedient accomplishment of many tasks, which were delayed because of the present constitution" would be enabled. It was highlighted that during the establishment of new areas' borders "great care has been taken that the new borders be natural", that is to say "they took in consideration communications and natural connections of certain areas and their respective centers. Finally, an attempt was made for the new division to be adjusted to the needs of the other administrative bodies. [...] New areas were named primarily after the great rivers which flow through those areas, since these names are already well known among the people, and they very clearly mark certain banovinas." - Записници MC KJ [Minutes MC KY], 99.

$10 \quad$ Ibid., 100.

11 B. Petranović, M. Zečević, Agonija dve Jugoslavije, (Beograd, 1991) [Agony of Two Yugoslavias, (Belgrade, 1991)], 90-91. 
banovinas. ${ }^{12}$ By identifying the Serbian issue with the problem of the Yugoslav state's survival, the ruling regime was willing to sacrifice the interest of the Serbian people by fragmenting its national territory into eight banovinas and offering it a Yugoslav national identity, the new national identification. Therefore, there is an opinion in modern historiography, according to which the new administrative arrangement was the most damaging to the interest of the Serbian people. ${ }^{13}$ Thus, the introduction of King Aleksandar's absolute rule further strengthened the already existing stereotypes about Serbian hegemony in a mutual state and its tendency towards total domination among the existing anti-Yugoslav national and religious elements.

\section{Communists and the "6 January regime"}

Beside a few of "bourgeois politicians" (Dragoljub Jovanović, Anton Korošec, Svetozar Pribićević, Vlatko Maček) the regime's oppression was primarily focused on communists and their sympathizers. Members of the Communist Party of Yugoslavia (hereinafter referred to as: CPY) and the League of Communist Youth of Yugoslavia (hereinafter referred to as: LCYY) were exposed to frequent persecutions and arrests. Already during 1929, the Central Committee (hereinafter referred to as: CC) had ceased operating as a monolithic leadership, while during April of the next year the Politburo was relocated abroad. Among the victims of the "white terror" were the CPY's Organizational Secretary Đuro Đaković and the secretary of the Red Help Nikola Haćimović, who according to the official report, were killed on 25 April 1929 at the Austrian-Yugoslav

12 Concerning the "breaking up" of Serbia in 1929, there had already been a previous division of country into smaller administrative units. Upon the implementation of the "Statute of the Division of Country into Administrative Areas" from April the $26^{\text {th }} 1922$, observed from within the borders of 1914, there were 15 out of 33 administrative units in total on the territory of Serbia. - Уредба о подели земље на области, Закон о општој управи, Закон о обласној и среској самоуправи, приредио др Михаило Илић, треће издање, (Београд, 1927) [Decree on the Division of Country into Regions, Law on General Administration, Law on the Regional and District Self-government, edited by Dr. Mihajlo Ilić, third edition, (Belgrade, 1927)], 11-16; B. Petranović, M. Zečević, Jugoslavija 1918-1984. Zbirka dokumenata, (Beograd, 1985) [Yugoslavia 1918-1984. Collection of Documents, (Belgrade, 1985)], 184-185.

13 B. Gligorijević, „Unutrašnje (administrativne) granice Jugoslavije između dva svetska rata 1918-1941", Istorija 20. veka ["Internal (Administrative) Borders of Yugoslavia Between the Two Wars 1918-1941", History of the 20 ${ }^{\text {th }}$ Century], 1-2/1992, 30-32; Popov, op. cit., 181. 
border, during an escape attempt. ${ }^{14}$ The Party's internal organization network was almost completely destroyed. ${ }^{15}$ However, this small, well organized Party with capable members - further strengthened by influx of young and well-disciplined members, who were fanatically loyal to the ideals of the world revolution, well-adjusted to non-parliamentary forms of struggle and highly conspiratorial modes of operation - managed to stand up to the regime with more success than it did in the early $1920 \mathrm{~s}$ when "Obznana" (1920) and the "Law for the Protection of Public Security and Order in the Sate" (1921) were passed.

The deep crisis which shook the Yugoslav state during 1928 was seen by communists as an unequivocal indicator of the breakdown of the "bourgeois system", while the murder and wounding of Croatian MPs was placed within the context of Serbian hegemony over Croats and other peoples and national minorities. ${ }^{16}$ Puniša Račić was presented in Party's announcements, as "an agent [...] of the ruling Serbian bourgeoisie and a clique of the court and generals", ${ }^{17}$ while the Croatian provincial leadership of the CPY kept emphasizing that with "the murder of the leaders of Croatian Peasant Party in the 'National' Assembly on October the $20^{\text {th }}$, the bourgeois government had shown [...] the way in which it wants to suppress Croatian agrarian movement in Croatia [underlined in the document itself - D. B.]"18

The events that occurred in the National Assembly placed the Croatian issue - which already had a dominant position in the national politics of most of the bourgeois parties and the CPY - at the focus of almost all political factors in country. The shots fired in the Parliament marked for the communists in Serbia the beginning of the armed strug-

14 More on this subject: Преглед историје Савеза комуниста Југославије, (Београд, 1963) [Overview of the History of the League of Communists of Yugoslavia, (Belgrade, 1963)], 161-179.

15 К. Николић, „Терористичка делатност Комунистичке партије Југославије у Краљевини СХC (1921-1930)“, Историјски гласник [K. Nikolić, "Terrorist Activity of the Communist Party of Yugoslavia in the Kingdome of SCS (1921-1930)", Historical Herald], 1-2/1993, 99.

16 D. Lukač, Radnički pokret u Jugoslaviji i nacionalno pitanje 1918-1941, (Beograd, 1972) [Workers' Movement in Yugoslavia and the National Question 1918-1941, (Belgrade, 1972)], 245-248.

$17 \mathrm{AY}$, fund of Communist Youth International (hereinafter referred to as: CYI), $1928 / 55$.

18 AY, fund of Central Committee of the League of Communists of Yugoslavia (hereinafter referred to as: CC LCY), Corpus Croatia, I/2. The leadership of the CPYs Local Committee in Zagreb said that after the events that occurred in the National Assembly, Stjepan Radić was poisoned in a hospital, on the order of the Yugoslav regime. - AY, fund of Communist International (hereinafter referred to as: CI), 1928/69. 
gle for the national emancipation of Croats. The secretariat of the CPY for Serbia issued a proclamation on the same day, aimed at the "working people of towns and countryside", which assessed that "it was high time for the Croatian people to shatter those shameful fetters and to gain freedom and its national emancipation in an open fight against the rulers in Belgrade". That emancipation would be expressed in the formation of the "independent Croatian republic". ${ }^{19}$ The slogan of "independent Croatia", without the mention of the rest of Yugoslav provinces, was posted in the proclamation of the CPY's Local Committee in Zagreb, regarding the death of Stjepan Radić on 8 August $1928 .^{20}$ Representatives of the LCYY held an opinion that "never before had the Croatian people been so exploited, so cheated and murdered as under the bloody Serbian government of financial magnates" concluding that "this [1928] regime was worse than Russian tsarist regime". ${ }^{21}$ According to historical research, during the second half of 1928, a more serious resistance against the regime, through organization of protests and strikes, was offered by the communists, but only in Zagreb, while in other cities there was only passive resistance, due to undeveloped connection between Party cells. ${ }^{22}$ In a wider perspective the Yugoslav communists spoke about the creation of a "federation of free worker-peasant republics", which would encompass Yugoslavia, Bulgaria, Romania, Greece and Albania. ${ }^{23}$

Leaders of the world workers movement within the Communist International (hereinafter referred to as: $\mathrm{CI}$, Comintern) have insisted on armed combat to be organized inside the Serbia itself, which was viewed

19 In the proclamation of the provincial Party subdivision in Serbia, full solidarity with the Croatian people had been expressed: "In that justified struggle against the hegemonistic bourgeoisie and militaristic monarchy, which is the greatest enemy of, not only Croatian people, but of the Serbian working people as well, the working class of Yugoslavia, together with Serbian workers at its front, shall be alongside the Croatian people with both its body and soul." - AY, CI, 1928/42.

20 The text of the proclamation of the CPY's Local Committee in Zagreb on August the 8 1928, mentions that Stjepan Radić perished because of "the Great-Serbian fascist power holders" which first "wounded him in the Parliament and then poisoned him in a Belgrade hospital". On the day of Stjepan Radić's funeral the Local Committee in Zagreb announced a general workers strike "as a sign of protest against barbaric and murderous government, which beats, poisons and murders its political adversaries". - AY, CI, 1928/69.

21 AY, fund of the Central Committee of the League of Communist Youth of Yugoslavia (hereinafter referred to as: CC LCYY), 1928/11, 1.

22 B. Gligorijević, Kominterna, jugoslovensko i srpsko pitanje, (Beograd,1992) [Comitern, the Yugoslav and Serbian Question, (Belgrade, 1992)], 243-244; S. Cvetković, Idejne borbe u KPJ, (Beograd, 1985) [Ideological Conflicts in the CPY, (Belgrade 1985)], 209-210; Lukač, op. cit., 249-264.

AY, CI, 1928/50, 1. 
as a political center and a stronghold of monarchy and "ruling Belgrade oligarchy". A "letter for Serbia" sent from Moscow in July 1928, said that "Yugoslav working masses outside of Serbia should hear the words of our workers and peasants from Serbia proper, and be assured that they are also fighting against the hegemony of Serbian bourgeoisie". ${ }^{24}$

At the end of the 1920s and the beginning of the 1930s, besides frequent accusations against the politics of the "Serbian bourgeoisie", the CPY also criticized the military leadership, the "court clique" and King Aleksandar as the personification of Yugoslav regime. For the communists, the Yugoslav monarch - "bloody eunuch King Aleksandar the Last" - was with "his lowly bootlickers - the generals" a representative of "big industrialists and landowners" ${ }^{25}$ In the proclamations of provincial subdivisions of the CPY, there were mentions of "the bandit gang headed by bloody and devious King Aleksandar", which "has been plundering and killing for a whole ten years", ${ }^{26}$ while according to the opinion of representatives of the "progressive youth", the Serbian bourgeoisie had strengthened its positions, "discarded the Croatian bourgeoisie like a drained peace of lemon and openly started to persecute and exploit Croatian bourgeoisie and Croatian paupers". ${ }^{27}$

Such strong statements made by the CPY against the Yugoslav regime and especially against the "Serbian bourgeoisie" were direct results of the process of bolshevization of the Party. During the 1920s, and especially after 1924, when the Comintern undertook to resolve the "Yugoslav issue", ${ }^{28}$ there were struggles within the CPY against "faction-

24 AY, CI, 1928/61. Communists from Serbia proper were told that "the masses in Serbia should be explained that it is in their best interest to take part in a mutual struggle with the Croatian people, against the mutual enemy". - AY, CI, 1928/76a, 7.

AY, CC LCY, Corpus Serbia, I/9.

26 AY, CI, 1928/46.

27 AY, CC LCYY, 1928/11, 1-2.

28 Besides the involvement in internal issues of the CPY at the beginning of the 1920s, Comintern strove to directly influence the situation in the Kingdom of SCS. CI saw the power with which it was possible to act against the "Great-Serbian" regime in the political activity of the Stjepan Radić, who was working on the internationalization of the Croatian issue since the 1922. At the invitation of the representative of the world workers movement, the leader of the Croatian Peasant Party came to Moscow at the beginning of June 1924, where he signed an agreement on the cooperation of the CPP and the Peasant International. CI directed its activity towards the "faction wars" - an internal issue of the CPY - at the beginning of 1925. By assuming the role of the "supreme arbitrator", the Comintern formed a Commission for the Yugoslav Issue, on March the $25^{\text {th }}$, whose members were, among the others, Joseph Stalin, Dmitry Manuilsky and Georgy Zinoviev. - More on this subject: G. Vlajčić, Jugoslavenska revolucija i nacionalno pitanje [Yugoslav Revolution and the National Question], (Zagreb, 1984), 143-156, 180-194. 
ism", "social democratic remnants", "liquidationism", "petty bourgeoisie tendencies", "anarcho-communist activities", "opportunism", "disloyalty", "reformism", and so forth. As far as the role of Comintern in the so-called "faction wars" within the CPY is concerned, there are numerous studies that show the "introduction of discipline" via the political isolation of prominent individuals of the older generations, who were adjusted to the pre-war methods of political activity and could not accept the abolition of pluralism in deliberation, under the slogan of building a monolithic world workers movement. ${ }^{29}$ In the process of eliminating "left wing" and "right wing" tendencies within the CPY, there was a particularly fierce struggle against the "group of Sima Marković", whose center was located in Belgrade. ${ }^{30}$

The aforementioned period (1924-1928) was marked by a radical shift in politics of the CPY towards the Yugoslav community. The thesis of "national unity" of Serbs, Croats and Slovenes was discarded, while the pro Yugoslav attitude from the beginning of the 1920s quickly faded away. ${ }^{31}$ The transformation of attitudes of the CPY in the spirit of dissolution of the Kingdom of SCS - viewed as a "Versailles" creation - coincided with the growing crisis in the country. Simultaneously, stereotypes were formed, on the hegemony of the Serbian, that is, the "Great-Serbian bourgeoisie", and Serbian people as a whole. Therefore, it is no coincidence that the conclusions of the Fourth Congress of the CPY, held in Dresden - four months after the events in the National Assembly had occurred - presented the highpoint of anti-Yugoslav, anti-Serbia and, as a final instance, general anti-Serbian sentiment in the Party. The policy of breaking up the mutual state by enforcing the people's right to selfdetermination and their complete emancipation was verified in 1926, at the Third Congress of the CPY and was further strengthened by the conclusion that the same right be given to the national minorities. In relation to that principle, there were mentions at the Fourth Congress of the CPY about the right of Hungarians and Germans in Vojvodina and Albanians ("Arnauts", "Shqiptars") in Kosovo and Metohija. Concerning the latter according to the Yugoslav communists - "one third of the Albanian population was under the rule of the Great-Serbian bourgeoisie against which it pursues the same oppressive regime, as it does in Macedonia", along

29 B. Jakšić, Svest socijalnog protesta. Ogled o međuratnom jugoslovenskom marksizmu, (Beograd, 1986) [Conscience of the Social protest. Essays on the Inter-war Yugoslav Marxism, (Belgrade, 1986)], 158.

30 AY, CI, 1927/17; AY, CI, 1927/25; AY, CI, 1927/29; AY, CI, 1927/62; AY, CI, 1928/7...

31 More on this subject: Д. Пешић, Југословенски комунисти и национално питање (1919-1935), (Београд, 1983) [D. Pešić, Yugoslav Communists and the National question (1919-1935), (Belgrade, 1983)], 82-244. 
with the permanent tendency "to occupy northern parts of Albania". Representatives of the CPY expressed "the solidarity of workers and peasants for other peoples of Yugoslavia, and above all Serbia, with Albanian national-revolutionary movement under the guidance of the Kosovo Committee", calling for "the working class to whole heartedly support the oppressed and fragmented Albanian people in their struggle for the independent and unified Albania". It is worthy noticing that the term "Albanian areas", within Party's rhetoric, included the areas "occupied in Macedonia and Kosovo". ${ }^{32}$

Introduction of King Aleksandar's absolute rule on 6 January1929, along with the institution of a tighter central administration in the country, followed by a wave of persecutions of both proven and suspected opponents of the regime, convinced communists even more in the "correctness" of their attitudes. Filip Filipović pointed out the "class character [...] of the union between Serbian, Croatian and Slovene great financial bourgeoisie under the monarchial hegemony". ${ }^{33}$ Within the Party, there was an opinion that the "autocracy in Yugoslavia" presents a "veil for the dictatorship of the Belgrade stock market". ${ }^{34}$ Institution of the dictatorship also presented a "brutal assault on the working class: it presents a barbaric exploitation of peasantry and further national oppression; it presents the weakening of petty bourgeoisie and firing of a great number of staff members". ${ }^{35}$

Beside what was already said, Party leaders spoke about the influence of foreign "capitalist" factors on the situation in the Kingdom of SCS. According to the words of Josip Čižinski ("Milan Gorkić") "the royal-military overthrow in Yugoslavia was not an independent and isolated fact, but a link in a common chain of politics of international imperialism". ${ }^{36}$ Thus, the attempts made to establish the central government in the mutual state were in concordance with the politics of the creation of "anti-Soviet block" in the Balkans. Filip Filipović wrote that "with the help of a wild and ruthless white terror, the bourgeoisie tries to maintain and solidify the rule of its class.

32 Историјски архив Комунистичке партије Југославије, том II: Конгреси и земаљске конференције КПЈ 1919-1937 (hereinafter referred to as: ИА КПЈ), (Београд, 1949) [Historical Archive of the Communist party of Yugoslavia, vol. II: Congresses and national Conferences of CPY 1919-1937, (hereinafter referred to as: $H A C P Y$ ), (Belgrade, 1949)], 152-163, 183.

33 F. Filipović, Sabrana dela, I-XIV, (Beograd, 1987-1989) [Collected Works, I-XIV, (Belgrade, 1987-1989)], XI/30.

34 AY, CI, 1929/4a, 3.

35 Filipović, op. cit., XI/36.

36 Revolucija pod okriljem Kominterne. Izabrani spisi Milana Gorkića, priredio i predgovor napisao Božidar Jakšić, (Beograd, 1987) [Revolution Under the Auspices of the Comintern. Selected Writings of Milan Gorkić, compiled and preface written by Božidar Jakšić, (Belgrade, 1987)], 131-137. 
[...] After ten years of bloody rule of its class, the Great-Serbian bourgeoisie openly treads on parliamentarism, the constitution and other products of bourgeois-democratic revolutions", because "it wants to be more independent towards special interests of certain capitalist groups; it wants to carry out politics which suit the interests of international imperialism [underlined in the document itself - D. B.] and Yugoslav upper bourgeoisie". Therefore "military coup d'état greatly increases danger of war", so "dictatorship" is a sign for "an uproar for the international proletariat as well". Belgrade was the center of "militarism" for the communists, so much more, because it was the "main center of the Russian military White Guard emigration".37

In the CPY's rhetoric of the inter bellum period, the thesis of the preparation for war, by the "Great-Serbian bourgeoisie", aimed at the institution of total dominance in the Balkans, did not fade, despite the ideological redirections and the dynamics according to which the Party's official politics were changing. ${ }^{38}$ For the sake of defending "the first country of socialism", the communists emphasized the slogan: "War against war". ${ }^{39}$ Expecting a quick breakdown of the Yugoslav state and the "Versailles system" in general, representatives of the CPY have, beginning from the 1928, paid special attention to "working in the army". At the Fourth Congress of the Party, the army of the Kingdom of SCS was seen as a "part of the bourgeois state apparatus, which the proletariat was obliged, not to democratize, but to crush". Exceptionally negative disposition of the CPY towards the military leadership was based on the already existing stereotypes about the "Great-Serbian bourgeoisie", since "in Yugoslavia, most of the officers came from the ruling [Serbian] nation". On the other hand, it was assessed that "most of the soldiers [...] came from the oppressed nations", and therefore "the conditions for revolutionary activity were very favorable". ${ }^{40}$

37 Filipović, op. cit., XI/31, 92-93, 189.

38 Communists believed that "the policy aimed at involving Yugoslavia in a war against USSR were also determined by the attitude of French and English imperialism towards Yugoslavia. These two countries were inclined to help the rule of the Great-Serbian bourgeoisie and militaristic monarchy as a main stronghold of their imperialism and the strongest military power in the Balkans, and also to give armament loans and loans for the construction of strategic railways and to reconcile the differences between the ruling bourgeoisie and the bourgeoisie of the oppressed nations, and finally to suppress revolutionary movements of working class, peasantry and oppressed nations". - ИА КПЈ [IA CРY], 189.

39 During the 1920s and the beginning of 1930s, Yugoslav communists said that "proletariat has a homeland that it has to defend - the Soviet Union - the homeland of the working class of all countries (underlined in the document itself - D. B.). - AY, CI, 1927/24-8, 13.

ИА КПЈ [ІА, СРҮ], 194-195. 
The communists considered the Yugoslav monarch to be a personification of "dictatorship" and "militarism". This opinion, which was common for the CPY, the separatist movements and most of the bourgeois politicians, was further strengthened by King's manner, his lifestyle, his work methods and his political activity. Among the recollections of the contemporaries it was noted that King Aleksandar appeared in public dressed in military uniform, almost every time, often carrying his personal arms (saber, pistol) and that he often had very close connections with his officers. ${ }^{41}$ By appointing division general Petar Živković, commander of the King's Guard and leader of the "White hand" officers' league, to the position of Prime Minister, the communists' judgment of King Aleksandar as a militaristic "dictator" was only reinforced.

Beside the strong influence of military factor ("militarism") and pronounced absolutism ("dictatorship"), fascism was, according to the communists, a third pillar of King Aleksandar's absolute rule. By examining the "ten year results" of life in a mutual state, communists considered that the "process of spreading fascism", which began in 1920, by passing "Obznana" and "breaking of the CPY", ${ }^{42}$ was running simultaneously with the "preparation" of the conditions for the introduction of the absolute

41 Both the study of memoirs and historiography agree in assessment that King Aleksandar, like his father Petar, was "born as a soldier", and that "his first court was a military tent, where he was educated and developed as a person". The development of his personality was highly influenced by the seven year long experience in the Balkan Wars and World War One (1912-1918), at the end of which he was crowned with victorious glory as the "Avenger of Kosovo". Years spent on the front have developed in Aleksandar Karađorđević a sense of discipline and a tendency towards an energetic, direct, and commanding communication with people. Those wartime years also introduced him to the world of non-parliamentary mode of rule and inspired disdain towards political parties and their leaders. In the years after 1918, the Yugoslav monarch was inclined towards absolute rule, not wanting to accept the role of a formal representative of the state, limited by the Constitution and the Parliament. More on this subject: Глигоријевић, Краљ Александар Карађорђевић [Gligorijević, King Aleksandar Karađorđević], I/3-304; Petranović, Zečević, Agonija dve Jugoslavije, 155-158, [Agony of Two Yugoslavias], 155-158; Записници MC KJ, Уводна студија [Minutes MC KY, Introductory Study], XXX-XXXIII.

42 AY, CC LCY, 1928/10, 1. A report from Slovenia says that as early as 1922, a "fascist movement was detected in that province, presented by an indigenous organization 'Orjuna'" (AY, CI, 1923/28, 1). According to the communists "the international Fascist movement was exceptionally well received in Yugoslavia, among the Yugoslav bourgeoisie of all tribes (ethnic groups)". In addition "the ruling [Serbian] bourgeoisie organizes a fascist organization for the combat against all other nations and tribes, in order to implement its hegemony through terror", [AY, CI, 1923/29$9,6]$. It was also pointed out that in the fight against the workers, the regime "is starting to use fascism on a greater scale (underlined in the document itself - D. B.)" - AY, CI, 1923/69, 1. 
rule of King Aleksandar. Even though in the Yugoslav case "fascism is trying to hide the dictatorship's class character", representatives of the CPY believed that the "the primary mission" of fascism and "fascist dictatorship" which "thirsts for workers' blood" 43 was "the destruction of revolutionary vanguard of working class". ${ }^{4}$

Simultaneously as it was fighting "class combat" against the "militaristic-fascist dictatorship", that is the "Great-Serbian" bourgeoisie, the CPY was emphasizing the national issue as the key issue for the resolving of existing crisis in the country. At the end of 1920s, national politics of the Party were based on the thesis of the supremacy - "hegemony" - of the Serbian bourgeoisie over other peoples. Therefore according to Josip Čižinski, "it was through autocracy that the concentration of the entire Yugoslav financial bourgeoisie under the leadership of its Serbian part [...] Disregarding the fact that there are five Croats and one Slovene ${ }^{45}$ within the government, we can view the overthrow as the end [...] of the ruling function of the Serbian bourgeoisie. Participation of the members of the Croatian upper bourgeoisie within the new government does not reduce the national-oppressive character of the Great-Serbian dictatorship." ${ }^{46}$ Filip Filipović considered the Kingdom of Yugoslavia to be a "great dungeon for all the oppressed peoples within it", that is "the darkest circle of Dante's Balkan Inferno". ${ }^{47}$

The Communists thought that "not only did the ten year long bloody regime of Great-Serbian bourgeoisie fail to solve the national and the peasant issue, but it even worsened national differences within Yugoslavia". ${ }^{48}$ Responsibility for the entire crisis in the country was borne by King Aleksandar, who "as an obedient and loyal instrument of the Great-Serbian bourgeoisie, energetically [...] worked on the concentration of all upper bourgeoisie elements of Yugoslavia under the hegemony of the Great-Serbs. With that aim he actively worked on the breaking up of national and religious parties." ${ }^{\prime 49}$ Even though the promo-

43 AY KOI, 1929/50, 1.

44 Filipović, op. cit., XI/30, 91-92.

45 Устави и владе Кнежевине Србије, Краљевине Србије, Краљевине СХС и Краљевине Југославије (1835-1941), приредио Душан Мрђеновић, (Београд, 1988) [Constitutions and Governments of the Principality of Serbia, Kingdome of Serbia, Kingdome of the SCS (1835-1941), edited by Dušan Mrđenović, (Belgrade, 1988)], 267-268; Записници МС KJ [Minutes of MC CY], 3-4.

46 Revolucija pod okriljem Kominterne. Izabrani spisi Milana Gorkića [Revolution Under the Auspices of the Comintern. Selected Writings of Milan Gorkic], 138-139.

47 Filipović, op. cit., XI/84, 228.

48 AY, CC LCY, 1928/10, 1.

49 Filipović, op. cit., XI/69. 
tion of the integral Yugoslav national identity as the new state ideology was performed at the expense of all national parties and associations, and carried out in all Yugoslav provinces, the communists believed that the Serbs and Serbia were in a highly privileged position. By identifying Yugoslav national identity with "Great-Serbianism", leaders of the CPY, after 6 January 1929, were saying that "all national, cultural and sport organizations in Croatia, Slovenia, Montenegro, Bosnia, Dalmatia and Vojvodina have been banned and their property confiscated. Instead of those organizations, fascist 'Yugoslav' ones were founded."

Beside the struggle for "national emancipation" of Croats, Slovenes and Montenegrins, at the end of the 1920s, a decision was made that "the Party must strengthen its activity within the national revolutionary movement of Macedonians, Albanians and so forth". ${ }^{11}$ In the aim of expanding the "revolutionary base" in the CPY's rhetoric, peoples' right to self-determination was expanded to cover national minorities. On the ideological plane the process of grouping all "oppressed peoples" in the aim of struggle against the "ruling nation" was on its way. Therefore, the CPY's Central Committee for Serbia called for the overthrow of the "main enemy of militaristic-fascist dictatorship and Great-Serbian monarchy", ${ }^{52}$ while the Party literature said how "never before was the hatred of oppressed nations - Croats, Macedonians, Slovenes, Montenegrins, Albanians, Germans, Hungarians, towards Serbiaas great, as it is now [1930]".53

Negative notions within the CPY about the Kingdom of SCS/Yugoslavia as an "expanded Serbia" created in a violent manner have arisen from the central world workers movement. ${ }^{54}$ Already at the middle of

\footnotetext{
50 Ibid., XI/183-184.

51 AY, fund Red Syndical International, 1929/2, 4.

52 AY, CC LCY, Corpus Serbia, I/5.

53 AY, CC LCY, 1930/2, 4.

54 Vlajčić, op. cit., 142-143. The term "Great Serbia" appears in a negative context for the first time at the so called "High Treason Trial" in Zagreb in 1908. Ljubomir Tadić mentions that the entry "Great-Serbian" was taken from the "vocabulary of AustroHungarian anti-Serbian propaganda”. - Љ. Тадић, $O$ „великосрпском хегемонизму“, (Београд, 1992) [Lj. Tadić, On the "Great Serbian Hegemonism”, (Belgrade, 1992)], 59-60. On the other hand, in the years that preceded the unification of Serbs, Croats and Slovenes, "Great Serbia" was most often mentioned by Serbs - both from Serbia proper and outside of it - but not in an affirmative or neutral way, and definitely not in a negative one. During the autumn of 1914, the state leadership of the Kingdom of Serbia was praising the "Serbian idea" aimed at the creation of powerful Slavic state in the Balkans, which would unite all Serbs, Croats and Slovenes. They considered that after the war, such a "strong and great Serbia, enlarged by Serbian and Croatian lands from Austro-Hungary" could secure a "balance in the Adriatic, and in certain way, in the Mediterranean as well". (quoted in: Dimić, op. cit., 9-12]. About the development of Serbian national program and "Great Serbia", more at: Popov, op. cit.
} 
the 1920s there were mentions of the "dictatorship of Old Serbia ${ }^{55}$ over the newly included areas". ${ }^{56}$ The Comintern warned that the strengthening of the position of the ruling regime could awaken the "the national oppression of Croats, Slovenes, Macedonians, Albanians, Montenegrins etc.", which would turn the Kingdom of SCS into a "Great Serbia in which [the regime] would try to denationalize all non-Serbian peoples". ${ }^{57} \mathrm{By}$ completely accepting the directives of CI, Yugoslav communists, after the events that occurred in the National Assembly in 1928, called for the "oppressed" and "working" people to fight against the "Serbian monarchy".58

\section{Terrorism in the CPY's activities and cooperation with Ustaše movement}

Party leadership viewed the introduction of King Aleksandar's absolute rule as a signal to raise the social revolution. ${ }^{59}$ During January 1929, Filip Filipović wrote how "numerous signs show that Yugoslavia is at the brink of civil war", while in addition the duty of the Party was to "provide political support to individual armed insurgencies, to keep them in unison and coordinate their activity, to connect them with the revolutionary combat of the city proletariat, to subordinate them to the common combat plan of the working class in the aim of overthrowing the military dictatorship" 60 The leadership of the CPY through its proclamation of 16 February 1929, called for the "working class", "petty and middle peasants" and "working masses of the oppressed nations" to embrace armed combat "in order to overthrow the bourgeois dictatorship and institute the rule of workers and peasants". ${ }^{61}$

However, circumstances in the Kingdom of Yugoslavia in the first half of 1929 were not in accordance with the expectations of the CPY. Even though the opinion that "with the introduction of absolutistic dictatorship the Yugoslav bourgeoisie did not manage to improve its shaken position at all" was still persistent, the leadership of the Party was forced to a conclusion at the extended session of CC's Politburo in May 1929 that "the revolutionary situation was not ripe". ${ }^{2}$ By temporarily suppressing

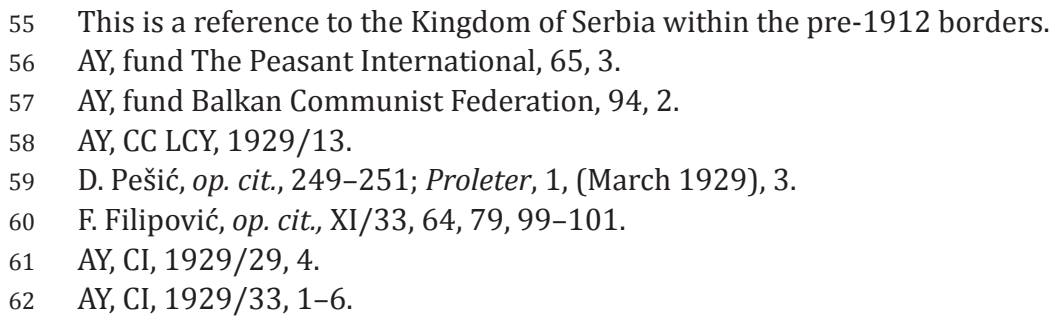


its direct action slogan, the CPY did not lose its revolutionary essence, but the thesis on an armed insurrection, after May 1929, returned its revolutionary character, instead. The idea of the violent overthrow of the state structure was still present among the communists, which saw the growth of "national dissatisfaction" in the numerous problems of the Yugoslav economic, social and political scene. ${ }^{63}$ Besides that, consequences of the economic crisis, whose duration coincided with the " 6 January dictatorship", was ignored in the Party propaganda.

Comintern stated its position on the raising of a revolution in Yugoslavia, quite late. In a letter sent to the leadership of the CPY on 30 May 1930 stands that the slogan of armed insurrection "still remains as a slogan of mass agitation, but that it is not an action slogan. Agitation for that slogan, in contemporary conditions, needs to explain, to the public masses, both the political need for an armed struggle for the overthrow of fascist dictatorship and the forms of practical preparation for the armed insurgence".64

The aforementioned attitude of the Comintern simultaneously implied the condemnation of "individual terror" as a mean of struggle of the CPY against Yugoslav regime. According to historical research, "terrorist disposition" among the communists, which was particularly expressed during 1929 and 1930, was a result of conviction and well measured politics of Party leadership. ${ }^{65}$ In this period members of the LCYY and the CPY who lost their lives in an armed conflict with the police, during arrest, were celebrated in the Party newspapers as heroes of the working class. ${ }^{66}$ However, after 1930 , these actions were discarded as an "expression of petty bourgeois despair". Party leadership concluded that "individual terror" cannot be of any use to the "working class and people's struggle", but causes "direct harm", instead. ${ }^{67}$ Contrary to undertaking individual acts, leadership of the CPY encouraged "penetration into the masses", that is, working on winning over "the masses of the working people".68

Communists found allies in their struggle against the "Belgrade power-holders" primarily within the Ustaše members, who also had a

63 Already in October 1929, it was assessed that there is a "deep revolutionary brewing among the working masses" which are "radicalizing" and "activating". - Filipović, op. cit., XI/156.

64 AY, CI, 1930/18a.

65 Gligorijević, Kominterna [Comintern], 245-247; Nikolić, op. cit., 145-146.

66 AY, CYI, 1929/37.

67 Revolucija pod okriljem Kominterne [Revolution Under the Auspices of the Comintern], 392-393.

68 Proleter, 28, (December 1932), 2. 
strong anti-Yugoslav disposition. The communists did not view the Croatian Party of Rights (hereinafter referred to as: CPR) as a fascist one, but as a "bourgeois-nationalist party which possesses a left wing [...] quite close to us". ${ }^{69}$ Planting reliable Party members into this "left wing" of the Ustaše movement was supposed to provide a permanent connection with the leadership of the CPR and in a further perspective take control of the entire movement. ${ }^{70}$ Principally, the communists condemned the cooperation of Ustaše with Italy and other "imperialistic powers". However, according to Josip Čižinski, "a temporary strategic compromise with the [foreign] imperialism [...] is permitted" in order to depose the Yugoslav regime. ${ }^{71}$ Therefore, the communists were acquiring their weaponry through fixed smuggling channels, leading from Italy to Hungary, through Yugoslav territories at the end of 1920s and beginning of 1930s. ${ }^{72}$

Leadership of the CPY expressed special solidarity with the Ustaše movement in September of 1932, during the so called Insurrection of Lika. The Communists marked this unsuccessful attack on a police station in Brušmani carried out by few Ustaše members as an uprising against the Yugoslav authorities. "The fact that the Ustaše movement is starting its actions in Lika and North Dalmatia - the poorest areas of Yugoslavia" meant, according to the Party leadership, that the social-economic and national moments "play a great role in that movement". Local subdivisions of the CPY were told that it was the "duty [...] of all communist organizations and every communist to support, organize and lead that movement". ${ }^{73}$ However, contrary to all expectations, there was no further escalation of the Insurrection.

\section{Beginning of the transformation of the CPY's territorial organization structure}

Anti-Yugoslav attitudes within the CPY were particularly augmented after the division of the state into banovinas in 1929. Party leadership believed that the "Great-Serbian bourgeoisie" wanted "to destroy every single national and historical characteristic of certain areas [...], to fragment national provinces and to suppress all legal possibilities for leading struggle for national emancipation" ${ }^{74}$ In their opinion, banovinas

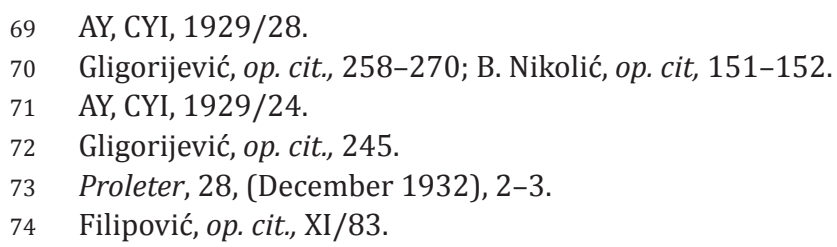


"in essence" present the "crown of national oppression", since the Law of 3 October "practically created Great Serbia [underlined in the document itself - D. B.]" ${ }^{75}$ By neglecting the real situation, the communists said that the formation of nine banovinas - "pashaluks"76 - "actually denotes the breaking up of Croatia, Bosnia, Macedonia, Montenegro, Vojvodina and Slovenia". ${ }^{77}$ Despite the rhetoric of the CPY, there can be no word about the "atomization" of the aforementioned provinces (except Bosnia and Herzegovina), because through the institution of new "inner borders, the historical continuity was not particularly broken up. In addition, among the preserved historical sources of Party provenance there is no mention of the division of Serbia into five banovinas.

During the 1920s and the beginning of 1930s, there were no particular discussions about situation in "Old Serbia" within the CPY. ${ }^{78}$ Due to regime's oppressive measures, ${ }^{79}$ part of the leadership had already left the country in the 1929, while the rest of the CC soon stopped acting as a unique body. Occasional reports from the 1931, assessed that the Party "is not active, it does not show signs of life".80 The Comintern undertook to address the situation within the CPY, as late as the middle of 1932, by performing the first "purge" of Yugoslav members and by forming a temporary leadership in Vienna, headed by Josip Čižinski. ${ }^{81}$ During the second half of 1932, the CPY was working on the restoration of Party structures in the country. ${ }^{82}$

Concerning the introduction of new administrative measures in the south of the country, the communists believed that "in order to colonize these areas as soon as possible" the territory of Kosovo and Metohija

75 AY, CC LCY, 1930/2, 3. The thesis of the CI and the CPY about the Kingdom of SCS as a "Great Serbia" was close to the positions of the CPP. Discussing with the leaders of Comintern in Moscow during June 1924, Stjepan Radić asserted that "in the current composition of the Peasant International [...] there can be no representative of Yugoslavia, because there is no Yugoslavia at this moment, only a militaristic and bandit Great Serbia under the name of Kingdom of Serbs, Croats and Slovenes". - AY, CI, 1924/37, 2.

76 AY, CI, 1930/2; Proleter, 8, (1 December, 1929), 1.

77 AY, CI, 1929/62, 6.

78 The term "Old Serbia" encompassed areas of former Kosovo eyalet, excluding Macedonia.

79 More on this subject: Dobrivojević, Državna represija [State Repression], 256-280.

80 AY, CI, 1931/4, 4. One report from January 1935 about the attitude of Party structures in a country says that during "1931, the CPY did not have its organization". - AY, CI, 1035/20, 5.

81 Gligorijević, op. cit., 248-253.

82 Преглед историје Савеза комуниста Југославије [Review of the History of the League of Communists of Yugoslavia], 161-190. 
"was split into three banovinas: Morava, Zeta and Vardar. [...] Dictatorship set the same goal as in the redistribution of land in Croatia, Bosnia and Dalmatia - the creation of Great-Serbian supremacy in the majority of banovinas and extension of aggressive political, economic and national oppression." ${ }^{\prime 3}$

After 3 October 1929, the CPY did not adapt its territorial organization structure to the new situation in the field, but instead it kept its old division into provincial, district, regional, county and local committees. This principle, based on the negation of the domestic politics of the Yugoslav authorities, was abandoned only in the area of "Old Serbia". So the process of separating Metohija, Kosovo and Sandžak from the CPY's PC for Serbia and the inclusion of the aforementioned areas into Montenegrin provincial organization was under way ${ }^{84}$ By deciding to separate the aforementioned areas from within the CPY's PC for Serbia, the communists acted in the spirit of "undoing the injustice", committed in the period of wars from 1912 to 1918 by the "Great-Serbian bourgeoisie", which "with the help of French imperialism conquered so many nonSerbian peoples by force". ${ }^{85}$ In that manner, leaders of the CPY wished to move closer to the "national-revolutionary" movements of the "oppressed" peoples, by which they especially meant the "Montenegrins" and the "Arnauts". In the latter case, the national policy of the CPY suffered a complete defeat during interbellum, because the communists did not manage to "penetrate into the Arnaut masses".

\section{Sources and literature}

\section{Sources}

- Архив Југославије. Фонд Управа казниона (Пожаревац, Сремска Митровица, Марибор): предмети осуђених комуниста (Archives of Yugoslavia. Administration of Penitentiaries funds (Požarevac, Sremska Mitrovica, Maribor): items of the convicted communists)

- Фонд Балканска комунистичка федерација (Archives of Yugoslavia. Fund Balkan Communist federation)

- Архив Југославије. Фонд Централни комитет Савеза комунистичке омладине Југославије (Archives of Yugoslavia. Fund of the Central Committee of the League of Communist Youth of Yugoslavia)

83 Proleter, 10, (20 January 1930), 5.

84 AY, CI, 1932/173-a; 1933/480.

85 AY, CC LCY, Corpus Serbia, I/7, 1. 
- Архив Југославије. Фонд Централни комитет Савеза комуниста Југославије, Збирка Србија (Archives of Yugoslavia. Fund of Central Committee of the League of Communists of Yugoslavia, Corpus Serbia)

- Архив Југославије. Фонд Централни комитет Савеза комуниста Југославије, Збирка Хрватска (Archives of Yugoslavia. Fund of Central Committee of the League of Communists of Yugoslavia, Corpus Croatia)

- Архив Југославије. Фонд Централни комитет Савеза комуниста Југославије (Archives of Yugoslavia. Fund of Central Committee of the League of Communists of Yugoslavia)

- Архив Југославије. Фонд Црвена синдикална интернационала (Archives of Yugoslavia. Fund Red Syndical International)

- Архив Југославије. Фонд Комунистичка интернационала (Archives of Yugoslavia. Fund of Communist International)

Newspapers and magazines

- Proleter (1929-1932)

\section{Literature}

1. Алманах Краљевине Југославије. IV јубиларни свезак: 19291931, друго издање. Загреб: Комисиона наклада Надбискупске тискаре, 1932.

2. Vlajčić, Gordana. Jugoslavenska revolucija i nacionalno pitanje. Zagreb: Centar za kulturnu djelatnost, 1984.

3. Gligorijević, Branislav. Kominterna, jugoslovensko i srpsko pitanje. Beograd: ISI, 1992.

4. Глигоријевић, Бранислав. Краљ Александар Карађорђевић, IIII. Београд: Завод за уџбенике, 2002.

5. Gligorijević, Branislav. „Unutrašnje (administrativne) granice Jugoslavije između dva svetska rata 1918-1941“. Istorija 20. veka 1-2/1992, 27-34.

6. Димић, Љубодраг. Историја српске државности, том III: Србија у Југославији. Нови Сад: САНУ, 2001.

7. Димић, Љубодраг. Срби и Југославија. Простор, друштво, политика (поглед с краја века). Београд: Стубови културе, 1998. 
8. Dobrivojević, Ivana. Državna represija u doba diktature kralja Aleksandra 1929-1935. Beograd: ISI, 2006.

9. Dobrivojević, Ivana. „Sudstvo i sudije u doba Šestojanuarskog režima kralja Aleksandra (1929-1935)“. Tokovi istorije 3-4/2005, 28-53.

10. Записници са седница Министарског савета Краљевине Југославије 1929-1931, приредили Љубодраг Димић и други. Београд: Службени лист СРЈ - Архив Југославије, 2002.

11. Историјски архив Комунистичке партије Југославије, том II: Конгреси и земаљске конференције КПЈ 1919-1937. Београд: Култура, 1949.

12. Jakšić, Božidar. Svest socijalnog protesta. Ogled o međuratnom jugoslovenskom marksizmu, Beograd: Institut za međunarodni radnički pokret, 1986.

13. Lukač, Dušan. Radnički pokret u Jugoslaviji i nacionalno pitanje 1918-1941. Beograd: ISI, 1972.

14. Николић, Коста. „Терористичка делатност Комунистичке партије Југославије у Краљевини СХС (1921-1930)“. Историјски гласник 1-2/1993, 91-101.

15. Petranović, Branko i Momčilo Zečević. Agonija dve Jugoslavije. Beograd: GIAP „Dragan Srnić“, 1991.

16. Petranović, Branko i Momčilo Zečević. Jugoslavija 1918-1984. Zbirka dokumenata. Beograd: Rad, 1985.

17. Petranović, Branko i Momčilo Zečević. Jugoslovenski federalizam. Ideje i stvarnost, Tematska zbirka dokumenata, I-II. Beograd: Prosveta, 1987.

18. Petranović, Branko. Istorija Jugoslavije, I-III. Beograd: Nolit, 1988.

19. Петрановић, Бранко. Југословенско искуство српске националне интеграције. Београд: Службени лист СРЈ, 1993.

20. Пешић, Десанка. Југословенски комунисти и национално питање (1919-1935). Београд: Рад, 1983.

21. Попов, Чедомир. Велика Србија. Стварност и мит. Треће издање. Сремски Карловци - Нови Сад: Издавачка књижница Зорана Стојановића, 2007.

22. Преглед историје Савеза комуниста Југославије. Београд: Култура, 1963.

23. Revolucija pod okriljem Kominterne. Izabrani spisi Milana Gorkića, priredio Božidar Jakšić. Beograd: Filip Višnjić, 1987.

24. Станковић, Ђорђе. Изазов нове историје, I-II. Београд: ВИНЦ, 1992-1994.

25. Stojkov, Todor. Opozicija u vreme šestojanuarske diktature 19291935. Beograd: Prosveta, 1969. 
26. Тадић, Љубомир. $O$ „великосрпском хегемонизму“. Београд: Стручна књига, 1992.

27. Уредба о подели земље на области, Закон о општој управи, Закон о обласној и среској самоуправи, треће издање, приредио Михаило Илић. Београд: Издавачка књижница Геце Кона, 1927.

28. Уставиивладе Кнежевине Србије, Краљевине Србије, Краљевине СХС и Краљевине Југославије (1835-1941), приредио Душан Мрђеновић. Београд: Нова књига, 1988.

29. Filipović, Filip. Sabrana dela, I-XIV. Beograd: ISI, 1987-1989.

30. Cvetković, Slavoljub. Idejne borbe u KPJ. Beograd: ISI, 1985.

\section{Резиме}

Душан БОЈКОВИТ

\section{Комунистичка партија Југославије у периоду личне власти краља Александра Карађорђевића}

Апстракт: У раду су представљени резултати истраживања: односа руководства Комунистичке партије Југославије према режиму током шестојануарске диктатуре Александра Карађорђевића, потом проблема сарадње комуниста са усташама и промене у територијално-организационој структури Партије почетком тридесетих година. Анализом су обухваћени архивски и објављени извори централног, покрајинских и обласних партијских актива, као и написи у штампи и релевантна литература.

Кључне речи: Краљевина Југославија, Комунистичка партија Југославије, „диктатура“, великосрпски хегемонизам, бановине

Убиство и рањавање посланика Сељачко-демократске коалиције у Народној скупштини 20. јуна 1928. означили су врхунац политичке кризе у Краљевини Срба, Хрвата и Словенаца. Након завођења личног режима 6. јануара 1929. краљ Александар Карађорђевић је наступао као чувар народног и државног јединства, док је укидање парламентаризма правдано увођењем реда у политички живот путем уклањања посредника између суверена и наро- 
да. Усвајање новог назива државе - Краљевина Југославија - симболично је означило одбацивање концепта очувања племенских обележја „југословенске нације“. Брисање старих граница међу историјским покрајинама и увођење административне поделе на бановине 3. октобра 1929. требало је додатно да учврсти и централизује Краљевину.

Предводници Комунистичке партије Југославије су у догађајима из 1928. и 1929. најпре видели остварење услова за спровођење социјалне револуције. У партијској штампи указивано је на заоштравање класних супротности у земљи, апсолутистичку природу владавине краља Александра, фашистичку и милитаристичку суштину југословенског режима и на неповољан положај несрпских народа и националних мањина. Комунисти су игнорисали нове административне границе у Краљевини, задржавајући у територијално-организационој структури Партије ранију поделу на покрајинске и обласне комитете. Изузетак је начињен једино на простору „Старе Србије“, па су упоредо са обновом партијских структура током 1932. и 1933. Косово, Метохија и Санџак издвојени из састава Покрајинског комитета КПЈ за Србију и придодати црногорској покрајинској организацији. 